\title{
Accounting
}

\section{The effect of the quality of electronic banking services on improving the level of communication and building trust with customers: case of the MENA countries}

\author{
Abdullah Alwehabie ${ }^{a^{*}}$

\begin{tabular}{l}
\hline C H R O N I C L E \\
\hline Article history: \\
Received May 152020 \\
Received in revised format May \\
162020 \\
Accepted July 62020 \\
Available online \\
July 62020 \\
\hline Keywords: \\
E-services innovation \\
Quality of banking services \\
Confidence building \\
Communication enhancement \\
MENA countries
\end{tabular}

${ }^{a}$ College of Business and Economics, Qassim University, Saudi Arabia

A B S T R A C T

In view of the increasing development of multi-channel services distributed by banks, the customer can receive the service through an electronic distribution system. For this reason, this study focuses on examining the relationship between the dimensions of online banking quality and customer satisfaction. Data were collected through a questionnaire, which was distributed to 1,275 customers of 85 banks in the Middle East and North Africa (MENA). The data were statistically analyzed using a structural equation model with SPSS. The results show that trust and communication had significant impacts on customer satisfaction.

\section{Introduction}

The banking sector is the most important economic sector in both developed and developing countries and is considered to be the cornerstone of economic life since banks are the preferred intermediaries between savers and investors (Ponsignon et al., 2015). Moreover, the role of banks is so important in the economy that it is the central pillar of the economy and, therefore, one of the main objectives of banks is to finance and encourage investment in the community where they operate and to create wealth through the provision of total quality banking services in order to gain the full confidence of customers. On the other hand, through the development of information and communication technologies, such as online banking, have become alternatives to traditional methods of service delivery, such as face-to-face banking. As a result, quality of service has become of great interest to banks in order to provide better service that best satisfies the customer (Alalwan et al., 2017). Therefore, it seems very important to know, in terms of service quality and overall customer satisfaction (Nkem \& Akujinma, 2017; Bolton et al., 2018). The problem of this research revolves around the moderator effect of the quality of services on communication between banks and their customers and on the establishment of trust with them in the Middle East and North Africa (MENA).

\section{Literature Review}

\subsection{The impact of e-services innovation on Bank performance}

E-Banking or online banking, or the distribution of financial services offered through electronic systems has been analyzed by several theorists among them Lustsik (2004) who defined online banking as a variety of electronic channels for conducting

* Corresponding author.

E-mail address: W.Abdullah@qu.edu.sa (A. Alwehabie)

(C) 2020 by the authors; licensee Growing Science, Canada doi: $10.5267 /$ j.ac.2020.7.003 
banking transactions over the Internet, telephone, television, mobile phone and computer. Today, customers can enjoy their banking transactions anywhere and anytime without going to their bank's head office or branches. Therefore, the required quality of online banking services must be present, characterized by independence, elasticity, freedom, and flexibility, in order to meet these desires (Khalfan \& Alshawaf, 2004; Lejeune et al., 2001). Internet banking has become an important channel of provide the services for the banks and carry out the transaction and other banking activities that are much easier for customers and considered to be the most important way to reduce costs and maintain or improve services to consumers. In this way, the quality of online services was seen as having the potential to in order to provide not only strategic advantages, but also to strengthen operational efficiency and profitability (Cronin, 2000). The analysis of the quality of online banking is becoming an increasingly important area of research interest to researchers and managers (Jayawardhena, 2004, Joseph et al., 1999; Novokreshchenova et al., 2016). With advances in technology, the sophistication of the needs of customers and the environment more and more competitive, the emphasis is on the quality of the website. The website functions as a window through which users have their first interaction with the organization (Zhang \& Von Dran, 2002).

\subsection{The Quality banking services based on the adoption of e-services innovation and its impact on online customer satisfaction and loyalty}

According to Kotler and Dubois (2003), the concept of quality consists of "a set of characteristics of a product or a service that affect its capacity to satisfy expressed or implied needs". In fact, several authors define service quality as an attitude, an evaluation (Cronin Jr. \& Taylor, 1992), or an overall judgement of its superiority (Parasuraman, Zeithaml, \& Berry, 1985). Besides, service quality is effectively the result of a cognitive assessment of a service while disregarding the transaction. Therefore, the abundance of definitions explains the existence of a typology in which the perceived quality or the perception mode of the offered service differs from the expected quality or simply from the customer's expectations (Anantharanthan Parasuraman et al., 1985). For their part, Parasuraman et al. (1985) were the first to respond to this need with the SERVQUAL scale of five dimensions (Reliability, Tangibility, Serviability, Empathy, and Assurance) and 22 items, initially applied in the retail trade (Parasuraman, Zeithaml, \& Berry, 1988). Moreover, the perceived quality of the banking service determines the customer's satisfaction and can make the customer a cognitively or emotionally committed actor towards his bank, just as it can also identify the satisfaction of the latter since it acts on the commitment of the customer to the bank (Asiyanbi \& Ishola, 2018). Loyalty is defined as repeated buying behavior presented over a period of time by a favorable attitude towards the subject (Keller, 1993), including attitudes and behavioral aspects.

Online loyalty "e-loyalty" is thus defined as the customer's favorable attitude and commitment to online banking, which is reflected in repeated use behavior (Srinivasan et al (2002). This loyalty to the service depends on the development of interpersonal relationships such as trust and reliability. Researchers have recognized that customer loyalty is a key path for banks to be competitive and profitable and to grow in order to survive (Anderson \& Srinivasan, 2003). According to Srinivasan et al (2002), e-loyalty is defined as the customer's favorable relationship attitude towards the online retailer that is reflected in repeated buying behavior. Therefore, e-loyalty concerns a customer's interest and intention to buy from the supplier in the future. Given the critical importance of customer loyalty, the literature has identified various antecedents affecting loyalty in an online context, including satisfaction, better communication and trust (Zeithaml et al., 1996). Studies have identified E-satisfaction as one of the main drivers of E-loyalty in the online services sector. (Ribbink et al., 2004), which means that if a customer is satisfied with a service, they are likely to become loyal. According to Chang et al. (1996) satisfied customers are more likely to return for repeat purchases from an e-commerce company. Thus, if a customer is satisfied, he or she has less intention of changing businesses online (Kim et al. 2009). Satisfied customers are more likely to recommend the service to others and spread positive word-of-mouth. They are also less likely to look for alternatives and turn to competitors (Andersen and Srinavasan, 2003).

\subsection{Moderating effects of the relationship quality in the banking sector and in the relationship between using the E-Service Innovation and confidence building}

To satisfy its customers, the bank should improve the quality of its services by adopting innovation in its electronic services (Nunkoo et al., 2017). This relationship between quality and satisfaction explains why banks use satisfaction measures to evaluate the quality approach. In the field of banks and financial institutions, a series of studies examined the relationship between the service quality and the customer's satisfaction. The results showed that the studied relationship is not limited only to the product but it also deals with the interactions between the customer and the bank. However, it does address the factors that explain the affective and cognitive engagement. For example, the quality of the banking service perceived by the customer stimulates the customer's affection for the bank and leads him or her to believe that it outperforms that of other customers). On the other hand, the innovation service can improve the service provided to the customer therefore, it must be properly exploited in order to generate a competitive advantage (Morgan \& Hunt, 1994; Crosby et al., 1990; Shaikh \& Karjaluoto, 2015, Shankar \& Jebarajakirthy, 2019). The literature has traditionally focused on confidence as a mechanism to reduce the transactions costs (Morgan \& Hunt, 1994), promote transparency in relationships, cooperation and information sharing, and reduce risk (Doney 
\& Cannon, 1997). More recently, research has focused on confidence as a mechanism for enhancing values in inter-firm relationships, particularly in the domain of banking services. Online trust is seen as an important factor in establishing and maintaining a strong relationship between a company and its customer (Reichheld \& Schefter, 2000). According to Jin et al. (2010), E-confidence is defined as the belief or trust of the customer in credibility and goodwill, which means that customers can rely on promises. The trust requirement is more complex in the virtual environment as online transactions are more impersonal, anonymous and automated than offline. A great deal of research has been conducted to examine the relationship between e-confidence and e-loyalty in e-commerce. Building trust is important because it has the ability to maintain and build long-term relationships with clients and therefore retain them (Kassim \& Abdullah, 2010). According to Reichheld and Schefter (2000), electronic trust is a precondition for obtaining loyalty and customer loyalty, as an online transaction is often perceived as having a higher risk of loss of personal information. However, despite the plurality of definitions of confidence, there is a consensus in the literature that it is the belief, the attitude or the expectation that the exchange partner's behavior will be directed in favor of the interests of the trusting party. This leads us to propose the following hypothesis:

H1: The quality of the relationship between banking services plays a moderating role in the relationship between innovation in e-services and confidence building.

\subsection{The moderating effects of the quality of relationships in banking services in the relationship between using the E-Service Innovation and improved Communication}

As a result, banks are obliged to review their commercial strategies by reorienting their communication campaigns and changing the tools they use in order to maintain their competitive positions, increase their market share and ensure their sustainability. In addition, to achieve their objectives, banks should get adapted to new expectations and changes in behavior in order to satisfy their customers and also develop new communication procedures (Amato-McCoy, 2005; Afthanorhan et al., 2019). In fact, today banks are starting to use new audience channels that are different from the traditional media. Besides, the strategic games, the virtual universes and the social networks represent new communication tools to be exploited. These channels are usually integrated into the communication strategies of the financial institutions because they can be visible to a particularly attractive target and a young population. Therefore, these means offer banks the opportunity to interact directly with their customers.

On the other hand, with the arrival of digital technology, there have been real technological advances in the banking sector. For example, Big data, Blockchain and Artificial Intelligence led to major transformations in the banks' trading and communication strategies. In fact, for a bank, one of the major specificities of its activities lies in the intangible or even the immaterial nature of the offer where one can neither see nor touch a service. Moreover, the customer participates in the production of the service of which he is the beneficiary. Therefore, when we consider a service as a system, we can identify at least three categories of interactions that influence the perceived image of the bank across two aspects, namely the speed and accessibility to the offered service while maintaining its quality (Bei \& Chiao, 2001). On the other hand, according to Gronroos (1996), it is through the tactical elements of relational marketing that the quality of service dimension manifests itself. In fact, the relational approach, on the one hand, favors direct contact with the customer in order to increase the confidence capital within the relationship and, on the other hand, it ensures a better knowledge of the customer and his profile through the implementation of databases enabling the company to offer a tailor-made service. Therefore, confidence is one of the determinants of the service quality (Parasuraman et al., 1985). Moreover, the interactive nature of ICTs, including innovation in e-services, enables better communication and reduces the information gap between the organizational customer and the bank. Therefore, for us, the bank is a special company because of the nature of the product it markets, namely the service. In fact, for a company, like the bank, one of the major specificities of its activities is the intangible or even the immaterial nature of the offer (Badoc, 1986; Tseng et al., 2004), hence, one can neither touch nor see a service. Moreover, the customer participates in the production of the service of which he or she is the beneficiary. Even more, the image is also affected by other elements, such as the communication strategy, the reputation of the management and the company's brand (Shareef et al., 2018). In addition to these elements, there are other aspects that are very important in the field of a pure service (Marjanovic \& Murthy, 2016). These are the elements of contact during the meetings between customers and service providers, namely the personnel in contact and the physical environment, the contribution of which is very significant both in the appreciation of the quality of the service offer and in the formation of the company's image (De Leaniz et al., 2016). In a context of an intensified competition and a lack of differentiation of the services offered by banks, satisfaction and loyalty have become a priority for managers, particularly in the financial sector where deregulation created an environment offering several options to meet the same customer's needs. Now, outside banks and traditional networks, new players, such as insurers and major retailers, are seeking to delight a very large part of the bank's clientele by meeting their needs Khadem and Mousavi (2013). Faced with this new environment characterized by an intense competition, the sustainability of the banking sector and financial institutions depends on the implementation of a relational approach in which the customer is a key factor (Zollinger \& Lamarque, 1999; Yaseen \& El Qirem, 2018; Alnaser et al., 2018). In fact, this new approach differs from the transactional or conventional one in that it is based on the act of selling, on competitive advantage, and on the quality of product positioning and brand equity, hence the following hypothesis can be formulated: 
$\mathrm{H} 2$ : The quality of the relationships in the banking services plays a moderating role in the relationship between Innovation in eservices and communication improvement

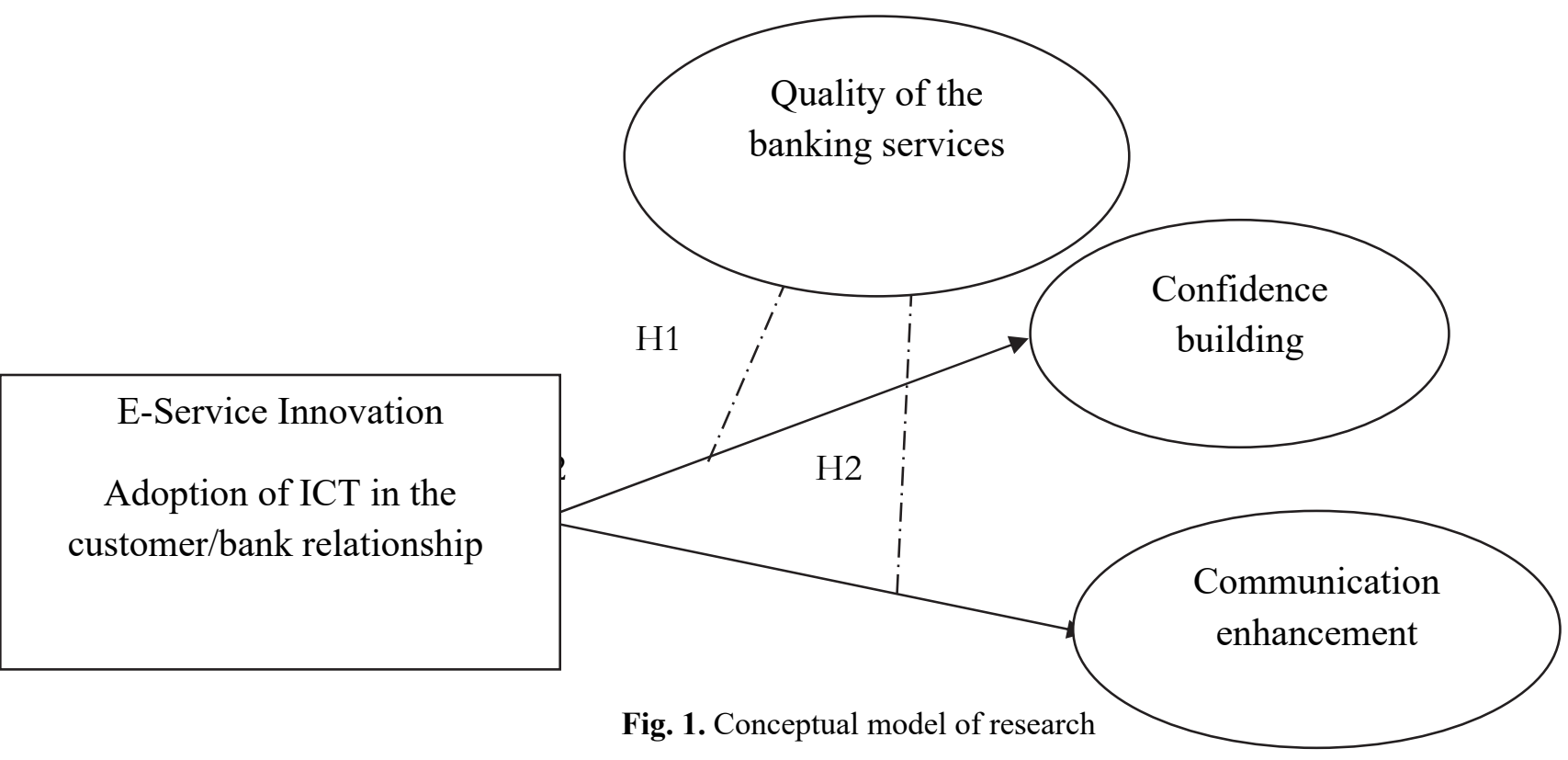

\section{Research methodology}

The sample is 1275 customers of 85 banks in the Middle East and North Africa (MENA). The questionnaires distributed by email, directly and through social means of communication. In fact, four criteria are frequently used in the validation of the multi-scale questionnaire. The first criterion consists in removing the items that have factor contribution greater above 0.30 on several factors, or with a contribution not reaching this score on one of the main selected factors. The second criterion recommends eliminating the items that have a contribution not greater than or equal to 0.50 on these same factors. It is on the basis of the results of the Principal Component Analysis (PCA) that either option is taken "without a priori preference". The third criterion consists in selecting factors the initial eigenvalues of which are greater than 1. Finally, the last criterion recommends selecting a number of axes that restore a percentage of the total variance to at least $50 \%$.

On the other hand, reliability brings the confirmation of the homogeneity of a scale that can have a one-dimensional or multidimensional construction. In fact, reliability is a necessary but not a sufficient condition of validity the objective of which is to reduce random error. As for internal consistency, it informs us, through Cronbach's alpha, about the degree of correlation of each item of a scale at least with on other one. Therefore, these items precisely and only measure the analyzed construct and thus share a common notion. The alpha coefficient estimates the variance of the total score of the common factors specific to the items of the tested scale. We focus on checking the discriminating validity of concepts, such as "the quality of the relationship in banking services", "confidence building" and "valuing communication". We are also interested in checking whether the measurement of the relationship quality in the banking services varies between the "confidence building" and "communication valuation" concepts.

The methodology adopted here consists in verifying if the latent variable (Relationship Quality in Banking) shares more variances with its measures than with the other variables. As a practical matter, the extracted mean variance $(\rho \mathrm{VC})$ is greater than the square of the correlation between the latent variables. The matrix diagonal shows the shared variances between the constructs and their measures $(\rho \mathrm{VC})$, while the rest of the matrix shows the square correlations between the scales. Therefore, our approach is presented in detail in two steps; the first establishes the reliability and validity of the measurements and the second tests the structural relationships between the latent constructs. Moreover, the corresponding data collection analyses consist in ensuring both the quality of our purified scales [Confirmatory Factor Analysis (CFA)] and the structural equation. Finally, to explain all the possible combinations of the background associated with good communication valuation, we used the Qualitative Comparative Analysis (QCA) to explain the complex interaction between the ICT adaptation, the relationship quality in banking, and confidence building. 
On the other hand, the Fuzzy/set Qualitative Comparative Analysis (F/sQCA) provides a method adapted to accommodate complex complementarities and non-linear relationships among constructions (Woodside, 2013; Othman et al., 2019). Therefore, this study enables to use the data analysis (CAEFQA) in order to compare and contrast the TSL results. Through this theme, we intend to operationalize the interactive effect of the ICT adaptation and confidence building on communication evaluation. In the literature, there are two research studies that reflected this effect, the first was conducted by (Zollinger, Monique and Lamarque, (1999) and the second by Zeithaml and Berry, (1985), who proposed respectively the interactive approach of the ICT and especially innovation in electronic services for the prediction of a better communication.

Then, the Weighted Triple Least-Squares (WLS) estimation method eliminates the structural differences among the banks in our sample by centering the data on their means. This method gives us short-term estimators. Nevertheless, centering the data with respect to their means could capture the full variance of the explanatory variable. In addition, the estimators used these two methods to test the nature of the interactions within the two triangles:

\section{* First triangle: ICT Adaptation - Quality of the relationship in SB and Trust Building}

\section{* Second triangle: ICT Adaptation - Quality of the relationship in SB and Communication evaluation}

As for the triple least squares method, it takes into account the likely correlation between the different equations. In fact, this estimation method starts by estimating each equation through the exogenous variables then, it uses the residuals of this first step to estimate the link between the hazards of the different equations. Regarding the empirical data in this study, they were collected through a field survey of 85 Saudi banks composing a sample based on the attributes of the bank's image and which were used regularly in the quality of the relationship in banking services, trust building and communication. In fact, all the exogenous variable measures use a 5-point Likert scale:1= extremely useful, $2=$ very useful, 3= somewhat useful, 4= not very useful, and $5=$ not at all useful. Finally, to reduce possible ambiguities, a pilot test was administered to the sample of 85 Arabic banks. For this reason, an exploratory factor analysis with a Varimax rotation was conducted to gather the data. Hence, the final interview was divided into three segments. The first assesses the quality of the relationship in the banking services, the second includes elements to measure confidence building and the third concerns the communication evaluation.

\section{Table 1}

Scale Selection

\begin{tabular}{|c|c|}
\hline Measurement items & Reference \\
\hline \multicolumn{2}{|l|}{ Relationship quality in the banking services } \\
\hline Good relationship with the local environment & Banerjee, (2002), Goyal and Joshi (2011) \\
\hline Membership and motivation of employees & Yaseen \& El Qirem (2018), Zollinger and Lamarque (1999) \\
\hline Better image / increase customer's loyalty & Chang et al. (1996), Srinivasan et al. (2002) \\
\hline $\begin{array}{l}\text { Improve communication and reduce the information gap between the organizational } \\
\text { customers and the bank }\end{array}$ & Yaseen \& El Qirem (2018) Zollinger and Lamarque (1999) \\
\hline Good quality of the offered service and the formation of the corporate image & Taylor and Baker (1994) \\
\hline \multicolumn{2}{|l|}{ Confidence building } \\
\hline Bank officials felt the need to quickly adopt this technology & Cooper and Zmud (1990), Chan and Lu (2004) \\
\hline Bank officials felt pressure from competitors to quickly adopt this technology & Shih and Fang (2004) \\
\hline Bank officials have ruled that this innovation is a bit complex for bank executives & Guo and Liang (2016) \\
\hline $\begin{array}{l}\text { The acceptance of this innovation was influenced by the personality traits (strong } \\
\text { personality, trust, insurance, ...) of the bank managers }\end{array}$ & Doyle and Bridgewater (2012) \\
\hline $\begin{array}{l}\text { Previous technology integration experiences have greatly helped in the adoption of this } \\
\text { innovation }\end{array}$ & Grisaffe (2007) \\
\hline One of the objectives was to improve the quality of services offered to customers & Makdadi and Al-Sukkar (2014) \\
\hline One of the goals was to strengthen the relationship with current customers & Adapa and Roy (2017) \\
\hline $\begin{array}{l}\text { One of the new customer objectives } \\
\text { Communication evaluation }\end{array}$ & Makdadi and Al-Sukkar (2014) \\
\hline Express your requirements more quickly at your bank & Makdadi and Al-Sukkar (2014) \\
\hline Receive better offers from your bank & van der Cruijsen \& Diepstraten (2017) \\
\hline Have an instant answer to your requests for banking services & Bülbül (2013) \\
\hline Obtaining complete and understandable bank information & Casu et al. (2010) \\
\hline Be better known by your bank & Casu et al. (2010) \\
\hline Improve your image with your bank & Javalgi et al. (1997) \\
\hline Improve your image with your customers & Nagaraju and Parthiban (2015) \\
\hline Perform banking transactions with greater security & Alt et al. 2018, Alt \& Puschmann (2012) \\
\hline Increase the volume of business with your bank & Kirakosyana and Dănăiaţăb (2014) \\
\hline Allow more communication & Darwish \& Lakhtaria (2011) \\
\hline
\end{tabular}




\section{Table 2}

Factor loadings and t-values for each measurement item

\begin{tabular}{|c|c|c|c|c|}
\hline Measurement items & Loading & t-value & Alpha & AVE \\
\hline \multicolumn{5}{|l|}{ Relationship quality in the banking services } \\
\hline Good relationship with the local environment & 0.647 & 25.23 & 0.847 & 0.799 \\
\hline Membership and motivation of employees & 0.744 & 13.47 & & \\
\hline Better image / increase customer's loyalty & 0.825 & 17.85 & & \\
\hline Improve communication and reduce the information gap between the organizational customers and the bank & 0.689 & 13.89 & & \\
\hline Good quality of the offered service and the formation of the corporate image & 0.756 & 17.92 & & \\
\hline \multicolumn{5}{|l|}{ Confidence building } \\
\hline Bank officials felt the need to quickly adopt this technology & 0.677 & 22.47 & 0.779 & 0.689 \\
\hline Bank officials felt pressure from competitors to quickly adopt this technology & 0.822 & 13.74 & & \\
\hline Bank officials have ruled that this innovation is a bit complex for bank executives & 0.642 & 18.82 & & \\
\hline $\begin{array}{l}\text { The acceptance of this innovation was influenced by the personality traits (strong personality, trust, insurance, ...) } \\
\text { of the bank managers }\end{array}$ & 0.739 & 17.63 & & \\
\hline Previous technology integration experiences have greatly helped in the adoption of this innovation & 0.881 & 29.17 & & \\
\hline One of the objectives was to improve the quality of services offered to customers & 0.691 & 33.74 & & \\
\hline One of the goals was to strengthen the relationship with current customers & 0.936 & 16.91 & & \\
\hline $\begin{array}{l}\text { One of the new customer objectives } \\
\text { Communication evaluation }\end{array}$ & 0.714 & 33.22 & & \\
\hline Express your requirements more quickly at your bank & 0.824 & 12.74 & 0.881 & 0.727 \\
\hline Receive better offers from your bank & 0.737 & 40.39 & & \\
\hline Have an instant answer to your requests for banking services & 0.678 & 17.28 & & \\
\hline Obtaining complete and understandable bank information & 0.699 & 29.14 & & \\
\hline Be better known by your bank & 0.769 & 11.58 & & \\
\hline Improve your image with your bank & 0.855 & 18.69 & & \\
\hline Improve your image with your customers & 0.688 & 20.78 & & \\
\hline Perform banking transactions with greater security & 0.828 & 17.89 & & \\
\hline Increase the volume of business with your bank & 0.765 & 17.98 & & \\
\hline Allow more communication & 0.678 & 30.11 & & \\
\hline
\end{tabular}

Note: Standardized factor loading, t statistics, Cranach's alpha, and average variance extracted (AVE) are displayed.

All t values are significant at 0.01 level.

In order to test our hypotheses, we followed the two-step method advocated by Anderson and Gerbing (1988). The first step consists in assessing the normality of our data, and the second is Hansen's test for multivariate normality, which shows that the variables, relationship quality in banking, confidence building, and communication valuation in this study, are non-normal (Chisquare $=1478.21, \mathrm{p}<0.001)$. For this reason, we used the Confirmatory Factor Analysis (CFA) with a robust maximum likelihood estimator. Then, we adopted the systems of equation regression algorithms to simultaneously test the moderating effect of the relationship quality in banking and in confidence building through the adoption of ICT in the customer/ bank relationship and in communication evaluation. This procedure was recommended because it derives the "score" factor from the measurement model and performs three-step least squares estimation (TSLS) for the systems of equations to cope with the problems of endogeneity and simultaneity. Therefore, since the two antecedents of ICT adoption in customer/banking relationship, such as confidence building and communication evaluation, are exogenous, their interaction is also exogenous. Moreover, the methodology adopted in the present research is intended to directly examine the interaction effect using the Two-Step Least Squares Model (TSLS), which contradicts the Partial Least Squares Analysis (PLSA) regression path. Furthermore, the systems of equation algorithms used to estimate the moderating effect of relationship quality in banking using the Structural Model Equation (SEM) for hypothesis testing are more appropriate than the PLSA algorithms because the latter are primarily tools of the exploratory analysis and therefore cannot be used for the hypothesis testing (Westland, 2010).

\section{Results and discussion}

All the PVC are greater than the correlation square between the moderator variable and the other variables in the model. The discriminant validity is therefore checked (Table 2). On the other hand, convergent validity was assessed by examining the factor loadings for each element of our measurement model. In fact, all the factor loadings are statistically significant at $\mathrm{p}<0.01$, as shown by the Multiple Correlation Square (MCS). Similarly, the resulting variance inflation factor values are all significantly lower than the cut-off of 10. Moreover, the item-item correlations were tested and the result showed that the correlations between the different items measuring confidence building, communication valuation, relationship quality in banking, and ICT adoption "are well below the value of 0.5 , therefore, multi-collinearity is not an issue in this study. Then, to test the robustness of the above results, we also implemented the PLS-PA algorithm to test the structural model. The obtained results are compatible with those of the simultaneous equation algorithm systems, which implies the empirical evidence of the robustness of our results. The results also showed that the correlations between ICT adoption and relationship quality in banking services are highly significant $(0.8417)$, indicating the validity of the proposed model. 
Table 3

Correlation matrix

\begin{tabular}{|c|c|c|c|c|}
\hline & Adoption of ICTs & $\begin{array}{l}\text { Quality of the } \\
\text { relationship in } S B\end{array}$ & $\begin{array}{c}\text { Confidence } \\
\text { Building }\end{array}$ & Communication \\
\hline Adoption of ICTS & 0.745 & & & \\
\hline Quality of the relationship in $S B$ & 0.8417 & 0.922 & & \\
\hline Confidence Building & 0.7141 & 0.6924 & 0.844 & \\
\hline Communication & 0.48972 & 0.7114 & 0.5881 & 0.84147 \\
\hline
\end{tabular}

Table 4

Results of the structural model using TLS with 95\% bootstrap CI

\begin{tabular}{lcc}
\hline Variables & Confidence building & Communication \\
\hline Adoption of ICTs & $0.2093222^{*}$ & $0.6529217 * * *$ \\
Quality of the relationship in SB & $0.58844003 * * *$ & $0.1632886 *$ \\
Constant & $0.8960389 * * *$ & $0.8826747 * *$ \\
$\mathrm{~N}$ & -0.000156385 & 0.0314406 \\
$\mathrm{R}^{2}$ & 0.4803 & 0.4769 \\
Mean VIF & 2.41 & 1.54 \\
\hline
\end{tabular}

Table 5

Configurations leading to communication enhancement

\begin{tabular}{lcc}
\hline Configurations & Raw coverage & Unique coverage \\
\hline Adoption of ICTs $\times$ Quality of the relationship in SB $\times$ Confidence building & 0.4404 & 0.3228 \\
Adoption of ICTs $\times$ Confidence building & 0.2339 \\
Total coverage 0.733 Solution consistency $=0.8557$ & 0.1995 \\
\hline
\end{tabular}

As it has been predicted, the moderating effect of the relationship quality in the banking services on the relationship between the ICT adaptation and confidence building is significant at the threshold of $1 \%(\mathrm{~b}=0.89603)$. In this context, the empirical results largely confirm the views of Morgan and Hunt (1994) and Andaleeb (1992) regarding confidence as a mechanism that can reduce the transaction costs, promote transparency in relationships, cooperation and information sharing. Furthermore, although the acceptance and development of relational marketing depends essentially on the rapid dissemination of ICTs, the good quality of the relationship in the banking services enable the bank to improve its efficiency, offer complementary services, innovate and maintain the customer's satisfaction and personalization. Furthermore, the results confirm the existence of a moderate effect on the quality of the relationship in the banking services and between the use of ICT and the valorisation of communication $(b=0.0826747)$. In fact, this effect, which is significant at $1 \%$ threshold, explains why the quality of the relationship in the banking services stimulates the customer's affection for the bank and leads him to believe that it surpasses its counterparts. Therefore, the results of our model confirm the theory of (Wolfinbarger \& Gilly 2003), which stipulates that the quality of the customer/bank relationship plays a key role in assessing the service quality and the customer's satisfaction, a dimension which is not directly found in the measures of physical service quality because it is relational. On the other hand, the FsQCA results, which validate the literature review and the personal reflections we have conducted, respond to this step. In fact, based on the theory of Lang and Colgate, (2003), Stoica et al. (2015), according to which the use of ICT and, in particular, innovation in e-services, improves communication and reduces the information gap between the organizational client and the bank, with a coherence threshold of 0.8557 , where the coherence index of the solution is similar to a correlation and the total coverage index is of the order of $73.3 \%$. As a result, each configuration constitutes a sufficient condition for the assessment of communication. Moreover, the combination of the use of ICTs and the quality of the relationship in the banking services is the only sufficient condition to simultaneously lead to the evaluation of communication for which the FsQCA has identified two configurations:

\section{The use of ICTs $\times$ Quality of the relationship in banking services $\times$ Confidence building $\rightarrow$ Valorisation of communication}

Finally, by comparing these solutions, it is clear that there is an interaction between the use of ICT and the quality of the banking relationship. For example, configuration 1 indicates that 91.12 per cent of all the banks in the sample have a better use of ICT, a good quality of the banking relationship, a good confidence building and a high value for communication. Alternative 2 indicates that the combination of a better use of ICT and a senior manager of confidence building leads to the valorisation of communication. Furthermore, our empirical results revealed that there is no effective practice at this level to reduce the effect of confidence building and ICT use on the valorization of communication. Gronroos (1996) explains this result by the fact that the quality dimension of the banking services manifests itself through the tactical elements of relational marketing. 


\section{Conclusion}

Our study covered 1275 customers of 85 banks in MENA countries and examined the degree of success in implementing ICT in communications between banks and their customers on the basis of trust in the face of major changes in information and communication technologies. Issues related to e-banking and customer relationship management in the context of MENA countries provide us with results that constitute an important managerial contribution for banks seeking to modernize their information systems, as it allows us to know the important factors for attracting more customers by using the new technology, and to encourage these customers to increasingly use these services by developing long-term relationships with them. This understanding then becomes an economic performance imperative for banks, as they are the ones who invest heavily in technology and allocate significant budgets to manage and improve relationships with their customers.

\section{References}

Adapa, S., \& Roy, S.K., (2017). Consumers' post-adoption behaviour towards Internet banking: Empirical evidence from Australia. Behaviour \& Information Technology, 36(9), 970-983.

Afthanorhan, A., Awang, Z., Rashid, N., Foziah, H., \& Ghazali, P. (2019). Assessing the effects of service quality on customer satisfaction. Management Science Letters, 9(1), 13-24.

Alalwan, A. A., Dwivedi, Y., Rana., (2017). Factors influencing adoption of mobile banking by Jordanian bank customers: Extending UTAUT2 with trust. International Journal of Information Management, 37(3), 99-110.

Alnaser, F., Ghani, M., \& Rahi, S. (2018). Service quality in Islamic banks: The role of PAKSERV model, customer satisfaction and customer loyalty. Accounting, 4(2), 63-72.

Alt, R., (2018). Electronic Markets and current general research. Electronic Markets, 28(2), 123-128. https://doi.org/10.1007/ s12525-018-0299-0.

Alt, R., \& Puschmann, T. (2012). The rise of customer-oriented banking - electronic markets are paving the way for change in the financial industry. Electronic Markets, 22(4), 203-215. https://doi.org/10. 1007/s12525-012-0106-2.

Amato-McCoy, D., (2005). Creating virtual value. Bank Systems and Technology, 1(22).

Anderson, R.E., \& Srinivasan, S.S. (2003). E-satisfaction and e-loyalty: A contingency framework. Psychology and Marketing, 20(2), 123-38.

Asiyanbi, H., \& Ishola, A. (2018). E-Banking services impact and customer satisfaction in selected bank branches in Ibadan metropolis, Oyo state, Nigeria. Accounting, 4(4), 153-160.

Banerjee, S. B. (2002). Corporate environmentalism: The construct and its measurement. Journal of Business Research, 55(1), 177-191.

Bei, L., \& Chiao, Y., (2001). An integrated model for the effects of perceived product, perceived service quality, and perceived price fairness on consumer satisfaction and loyalty. Journal of Consumer Satisfaction, Dissatisfaction and Complaining Behavior, 14, 125-40.

Bolton, R.N., McColl-Kennedy, J.R., Cheung, L., Gallan, A., Orsingher, C., Witell, L. and Zaki, M., (2018). Customer experience challenges: bringing together digital, physical and social realms. Journal of Service Management, 29(5), 776808.

Casu, B., Zhao, T., \& Ferrari, A. (2010). The impact of regulatory reforms on cost structure, ownership and competition in Indian banking. Journal of Banking \& Finance, 34, 246-254.

Chan, S.C., \& Lu, M.T. (2004). Understanding internet banking adoption and use behavior: a Hong Kong perspective. Journal of Global Information Management, 12, 21-43.

Chong, E., Kennedy, R., Riquire, C., \& Rungie, C. (1997). The Difference between Satisfaction and Service Quality', New and Evolving Paradigm: The Emerging Future of Marketing, The American Marketing Association's 1997 Special Conference, Dublin, 12-15 June.

Cooper, R.B., \& Zmud, R.W. (1990). Information technology implementation research: A technological diffusion approach. Management Science, 36, 123-139.

Cronin, J. J., Brady, M. K. \& Hult, G. T. M. (2000). Assessing the effects of quality, value, and customer satisfaction on consumer behavioral intentions in service environment. Journal of Retailing, 76 (2), 193-218.

Cronin, J.J., \& Taylor, S.A. (1992). Measuring service quality: A re-examination and extension. Journal of Marketing, 56(3), 55-68.

Crosby, L., Evans, K., \& Cowles, D. (1990). Relationship quality in services selling: An interpersonal influence perspective. Journal of Marketing, 54 (July), 68-81.

Darwish, A., \& Lakhtaria, K. I., (2011). The impact of the new Web 2.0 technologies in communication, development, and revolutions of societies. Journal of Advances in Information Technology, 2, 204-216

De Leaniz, P.M.G., Rodriguez, D.B., \& Rodriguez, I. (2016) Corporate image and reputation as drivers of customer loyalty. Corporate Reputation Review, 19, 166- 178. 
Doney, P.M., \& Cannon, J.P. (1997). An examination of the nature of trust in buyer-seller relationships. Journal of Marketing, 61(2), 35-51.

Doyle, P., \& Bridgewater, S. (2012). Innovation in marketing. Routledge

Goyal, K. A., \& Joshi, V., (2011). A study of social and ethical issues in banking industry. International Journal of Economics and Research, 2(5), 49-57.

Grönroos, C. (1994). From marketing mix to relationship marketing. Toward a paradigm shift in marketing. Management Decision, 32(2), 4-32.

Guo, Y., \& Liang, C. (2016). Blockchain application and outlook in the banking industry. Financial Innovation, $2(1), 24$.

Javalgi, R. R. G., \& Moberg, C. R. (1997). Service loyalty: implications for service providers. Journal of services marketing, 11 (3), 165-79.

Jayawardhena, C. (2004). Measurement of service quality in internet banking: The development of an instrument. Journal of Marketing Management, 20(1-2), 185-207

Jin, R., Hoi, S. C., \& Yang, T. (2010, October). Online multiple kernel learning: Algorithms and mistake bounds. In International conference on algorithmic learning theory (pp. 390-404). Springer, Berlin, Heidelberg.

Joseph, M., McClure, C., \& Joseph, B. (1999). Service quality in the banking sector: The impact of technology on service delivery. International Journal of Bank Marketing, 17(4),182-193.

Kassim, N., \& Abdullah, N. A. (2010). The effect of perceived service quality dimensions on customer satisfaction, trust, and loyalty in e-commerce settings. Asia Pacific Journal of Marketing and Logistics, 22(3), 351 - 371.

Keller, K.L. (1993). Conceptualizing, measuring, and managing customer-based brand equity. Journal of Marketing, 57, 1-22.

Khadem, P., \& Mousavi, S. (2013). Effects of self-service technology on customer value and customer readiness: The case of banking industry. Management Science Letters, 3, 2107-2112.

Khalfan, A. M., \& Alshawaf, A. (2004). Adoption and implementation problems of E-Banking: A study of the managerial perspective of the banking industry in Oman. Journal of Global Information Technology Management, 7(1), 47-64

Kim, J., Ma, Y.-J., \& Park, J. (2009). Are US consumers ready to adopt mobile technology for fashion goods? An integrated theoretical approach. Journal of Fashion Marketing and Management, 13(2), 215-230.

Kotler, P., \& Bernard, D. (2003). Marketing Management. Pearson Education, 11th Ed. (1977), Paris.

Kirakosyana, K., \& Dănăiaţăb, D. (2014), Communication management in electronic banking. Better communication for better relationship. Procedia - Social and Behavioral Sciences, doi: 10.1016/j.sbspro.2014.02.497

Lang, B., \& Colgate, M. (2003). Relationship quality, on-line banking and the information technology gap. International Journal of Bank Marketing, 21(1), 29-37.

Lustsik, O. (2004, November). Can E-Banking services be profitable? (University of Tartu Economics and Business Administration Working Paper No.30-2004). doi:10.2139/ssrn.612762

Makdadi, Y.A.A., \& Al-Sukkar, A.S. (2014). Determined factors of marketing innovation and its impact on improving the quality of banking services: An empirical study in Jordanian commercial banks. Mu'tah Research and Studies, Series of Humanities and Social Sciences, 29(3).

Marjanovic, O., \& Murthy, V. (2016). From product-centric to customercentric services in a financial institution - Exploring the organizational challenges of the transition process. Information Systems Frontiers, 18(3), 479-497.

Morgan, RM., \& Hunt, S.D. (1994). The commitment-trust theory of relationship marketing. Journal of Marketing. 58(July), 1994.

Nagaraju, S., Parthiban, L. (2015). Trusted framework for online banking in public cloud using multi-factor authentication and privacy protection gateway. Journal of Cloud Computing, 4 (22) (2015). https://doi.org/10.1186/s13677-015-0046-4

Nkem, I. S., \& Akujinma, A. F. (2017). Financial innovation and efficiency on the banking sub-sector: The case of deposit money banks and selected instruments of electronic banking. Asian Journal of Economics, Business and Accounting, 2(1), $1-12$

Novokreshchenova, O. A., Novokreshchenova, N. A., \& Terehin, S. E. (2016). Improving bank's customer service on the basis of quality management tools. European Research Studies Journal, 19(3), 19-38.

Nunkoo, R., Teeroovengadum, V., Thomas, P., \& Leonard, L. (2017). Integrating service quality as a second-order factor in a customer satisfaction and loyalty model. International Journal of Contemporary Hospitality Management, 29(12), 29783005 .

Othman, B., Harun, A., Rashid, W., \& Ali, R. (2019). The impact of Umrah service quality on customer satisfaction towards Umrah travel agents in Malaysia. Management Science Letters, 9(11), 1763-1772.

Parasuraman, A., Zeithaml, V. A., \& Berry, L. L. (1985). A conceptual model of service quality and its implications for future research. Journal of Marketing, 49(4).

Parasuraman, A., Zeithaml, V. A., \& Berry, L. L. (1988). Servqual. Journal of Retailing, 64(1), 12-37.

Ponsignon, F., Klaus, P., \& Maull, R. (2015). Experience co-creation in financial services: an empirical exploration. Journal of Service Management, 26(2), 295-320.

Reichheld, F. F., \& Schefter, P. (2000). iE-Loyalty: Your Secret Weapon on the Web. Harvard Business Review, 78(4), 2000, pp. $105-113$ 
Ribbink, D., van Riel Allard, C. R., Liljander, V., \& Streukens, S. (2004). Comfort your online customer: Quality, trust, and loyalty on the Internet. Managing Service Quality, 14(6), 446-56.

Shaikh, A.A., \& Karjaluoto, H. (2015). Mobile banking adoption: A literature review. Telematics and Informatics 32(1), 129142 .

Shankar, A., \& Jebarajakirthy, C. (2019). The influence of e-banking service quality on customer loyalty: a moderated mediation approach. International Journal of Bank Marketing, 37(5), 1119-1142.

Shareef, M. A., Mukerji, B., Alryalat, M. A. A., Wright, A., \& Dwivedi, Y. K. (2018). Advertisements on Facebook: Identifying the persuasive elements in the development of positive attitudes in consumers. Journal of Retailing and Consumer Services, 43, 258-268.

Shih, Y., \& Fang, K. (2004). The use of a decomposed theory of planned behavior to study Internet banking in Taiwan. Internet Research, 14, 213-223.

Srinivasan, S.S., Anderson, R.E., \& Ponnavolu, K. (2002). Customer loyalty in ecommerce: An exploration of its antecedents and consequences. Journal of Retailing, 78(1), 41-51.

Taylor, S.A., \& Baker, T.L. (1994). An assessment of the relationship between service quality and customer satisfaction in formation of consumers' purchase intentions. Journal of Retailing, 70, 163-178.

Tseng, C. H., Tansuhaj, P. S., \& Rose, J. (2004). Are strategic assets contributions or constraints for SMEs to go international? An empirical study of the US manufacturing sector. Journal of American Academy of Business, 5(1/2), $246-254$.

van der Cruijsen, C., \& Diepstraten, M. (2017). Banking products: you can take them with you, so why don't you?. Journal of Financial Services Research, 52(1-2), 123-154.

Westland, J.C. (2010). Lower bounds on sample size in structural equation modeling. Electronic Commercial Resources, 2, 476-487

Wolfinbarger, M. \& Gilly, M. (2003). E-TailQ: Dimensionalizing, measuring and predicting Etail quality. Journal of Retailing, 27, 183-198.

Woodside, A. G. (2013). Moving beyond multiple regression analysis to algorithms: Calling for a paradigm shift from symmetric to asymmetric thinking in data analysis, and crafting theory. Journal of Business Research, 66, 463-472.

Yaseen, S.G., \& El Qirem, I.A. (2018). Intention to use e-banking services in the Jordanian commercial banks. International Journal of Bank Marketing, 36(3), 557-571

Parasuraman, A., Zeithaml, V. A., \& Berry, L. L. (1985). A conceptual model of service quality and its implications for future research. Journal of Marketing, 49(4), 41-50.

Zeithaml, V. A., Berry, L.L. \& Parasuraman, A., (1996). The behavioural consequences of service quality. Journal of Marketing Management, 60(2), 31-46.

Zhang, P., \& von Dran, G. M. (2002). User expectations and rankings of quality factors in different web site domains. International Journal of Electronic Commerce, 6(2), 9e34.

Zollinger, M., \& Lamarque, É. (2008). Marketing et stratégie de la banque.

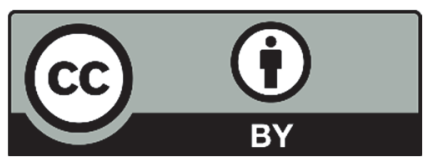

(C) 2020 by the authors; licensee Growing Science, Canada. This is an open access article distributed under the terms and conditions of the Creative Commons Attribution (CC-BY) license (http://creativecommons.org/licenses/by/4.0/). 